\title{
Tityosteus, A MARINE FISH (ARTHRODIRA, HOMOSTIIDAE) FROM THE EMSIAN OF ARAGÓN, SPAIN, AND ITS DISTRIBUTION
}

\author{
Elga MARK-KURIK ${ }^{1}$ and Peter CARLS $S^{2}$ \\ ${ }^{1}$ Institute of Geology. Tallinn University of Technology, Estonia Avenue 7, \\ 10143 Tallinn, Estonia. E-mail: kurik@gi.ee \\ ${ }^{2}$ Institut für Umweltgeologie, Technische Universität, Braunschweig, Pockels- \\ Str. 3, D 38106, Germany.
}

Mark-Kurik, E. and Carls, P. 2004. Tityosteus, a marine fish (Arthrodira, Homostiidae) from the Emsian of Aragón, Spain, and its distribution. [Tityosteus, un pez marino (Arthrodira, Homostiidae) del Emsiense de Aragón, España, y su distribución.] Revista Española de Paleontología, 19 (2), 139-144. ISSN 0213-6937.

\begin{abstract}
A right marginal plate (over $11 \mathrm{~cm}$ long) of Tityosteus cf. rieversae Gross, 1960, emend., has been found in the late part of the Early Emsian (late Zlichovian) in the Mariposas Fm. of the Eastern Iberian Cordillera in southern Aragón. The palaeoecological conditions correspond to a hemipelagic ensialic basin, with predominant elements of Hercynic biofacies but still with photic bottom. The Emsian genus Tityosteus is now known from the Hunsrück Schiefer of Germany and the closely connected Ibero-Armorican Trough and also from the more distant Minusinsk Basin of southern Siberia. Palaeo-oceans between western Europe and southern Siberia were no zoogeographical barriers for these large, possibly microphagous fishes in open sea. The name of the type species of Tityosteus is emended.
\end{abstract}

Keywords: Placodermi, marginal plate, palaeoecology, palaeozoogeography, late Zlichovian.

\section{RESUMEN}

Se describe una placa marginal derecha (más de $11 \mathrm{~cm}$ de longitud) de Tityosteus cf. rieversae Gross, 1960, emend., de la parte tardía del Emsiense Inferior (Zlichoviense tardío) de la Fm. Mariposas en la Cordillera Ibérica Oriental (sur de Aragón). Las condiciones paleoecológicas corresponden a una cuenca ensiálica, hemipelágica, con elementos predominantes de biofacies hercínica, pero aún con fondo fótico. Se comenta la distribución del género Tityosteus en las Pizarras del Hunsrück en Alemania y en la cercana Cuenca Ibero-Armoricana como también en la más distante Cuenca de Minusinsk de Siberia suroccidental. Los paleoocéanos existentes entre Europa occidental y Siberia meridional no serían barreras zoogeográficas para estos grandes peces de mar abierto, posiblemente micrófagos. Por último, se enmienda el nombre de la especie típica de Tityosteus.

Palabras clave: Placodermi, placa marginal, paleoecología, paleozoogeografía, Zlichoviense tardío.

\section{INTRODUCTION}

During a joint prospection for remains of early vertebrates in the Eastern Iberian Cordillera, guided by P. C. in summer of 1986, Dr. Hermann Mader, then holding a postdoc DFG fellowship at the Technical University of Braunschweig, found the disarticulated placoderm bone described here. The specimen was stratigraphically assigned and prepared by P. C., and the palaeoichthyological study was carried out by E. M.-K.
The locality has the U.T.M. co-ordinates X:662.360, Y:4551.750 on the topographical map $1: 25,000$, no. 466I, Villar de los Navarros; this corresponds to X:819.900, Y:725.170 on the geological map $1: 50,000$, no. 466, Moyuela (formerly Blesa). It is at the western one of two creeks that bear the name Regajo, near a garden in the area called Parideras. There is a steep slope SE above a left bend of the creek, $0.75 \mathrm{~km} \mathrm{~N}$ of the road from Bádenas to Loscos, $2.5 \mathrm{~km} \mathrm{SE}$ of the church of Santa Cruz de Nogueras, within the bounds of Loscos. 
The block with the fossil had fallen out of the steep outcrop and was found as float in the creek Regajo. It stems from one of the thicker packs of shale in the upper part of the section Regajo-Parideras. At this site, upper parts of the submember $d 4 b \alpha$ of the Mariposas Fm. are exposed. According to the local conditions, the shale layer with the bone belongs most probably to bed 162 or to its closest vicinity. Shale bed 162 is $1.2 \mathrm{~m}$ thick and its top is $0.7 \mathrm{~m}$ below the first limestone bed (165) with goniatites.

The Mariposas Fm. (local symbol d4) is 200 m thick. It consists mainly of shales, but the most characteristic levels are well bedded shelly, crinoidal, and partly marly limestones, which are concentrated in several intervals with thinner shale interbeds. All levels and faunas are laterally widely persistent, which allows a detailed lithostratigraphic and biostratigraphic subdivision throughout the region. The Mariposas Fm. ranges from the final Siegenian (in traditional sense; base of Middle excavatus Zone as marked at $114 \mathrm{~m}$ in the Zinzilban limitotype section of the Emsian, non gronbergi Zone) into an early part of the Late Emsian (early within the serotinus Zone). It has a well recognizable succession of numerous marine faunas including conodonts. The biofacies fluctuate between shallow neritic and hemipelagic conditions, according to frequent changes in water depth, hydrodynamics, and fine clastic input. Repeatedly, dacryoconarids occur. This allows the detailed correlation of the historical Rhenish stages and of their subdivisions with the Bohemian stages and with the conodont zonation. In the older faunas (member d4a), elements of neritic (Rhenish) biofacies predominate, especially strong-ribbed spiriferids. From the passage of member $\mathrm{d} 4 \mathrm{a}$ to member $\mathrm{d} 4 \mathrm{~b}$ onward, with early Nowakia (Dmitriella), early in the gronbergi Zone (in its sense practised in Europe), Bohemian trilobites and more and more elements of pelagic (Hercynic) biofacies appear, including orthoconic cephalopods, epiplankton (tiny Chonetacea) and plankton (Dacryoconarida). The contents in pyrite and organic matter increase upwards. The faunal change corresponds to a long-term gradual deepening that culminates at the Daleje Event with clear waters little below storm wave base. The occurrence of Tityosteus is already close to the maximum of the pelagic influence, but the predominant benthic trilobites with large eyes (mainly phacopids, some scutelluids) still indicate photic conditions in clear waters; additionally, longspined trilobites are present that were probably swimming (Odontopleuridae). Two cephalopod beds (165 and 167), beginning $0.7 \mathrm{~m}$ above the shale bed 162, contain Anetoceras (Erbenoceras), Palaeogoniatites, and Mimagoniatites zorgensis as well as various orthoconic cephalopods (some over $15 \mathrm{~cm}$ thick) and have furnished Nowakia barrandei at most localities. The Tityosteus bed may still be in the final part of the Nowakia praecursor Zone. In terms of the prevailing (actually unstable) conodont zo- nations, this Tityosteus specimen is from the nothoperbonus Zone. The first indexes of Late Emsian age are the Rhenish trilobites (Asteropyginae) Rhenops lethaeae and Kayserops cf. kochi which overlap with late Nowakia elegans (which had formerly been reported as $N$. cancellata), about a dozen of metres above the bed with Tityosteus.

The late Early Emsian (late Zlichovian) age and the environmental conditions of progressive deepening of the Spanish occurrence of Tityosteus parallel the conditions of its occurrence in the Hunsrück Schiefer of Bundenbach in Germany. As the goniatites of that level of the Hunsrück Schiefer correlate with Anetoceras of the Stadtfeld Beds of the Vallendar "Group", their Tityosteus rieversae is also from a rather late part of the classical Early Emsian. (Against the opinion of some geologists working in the Hunsrück region, the famous fossiliferous beds of the Hunsrück Schiefer of Bundenbach are not equivalents of the Ulmen "Group" that is early Early Emsian.)

We want to express the closeness and possible identity of our specimen to $T$. rieversae, the type species of Tityosteus; but having found only one plate, we prefer to identify it in open nomenclature, using "cf." (= confer = compare to).

Abbreviations: $\mathrm{C}=$ central plate; $\mathrm{C} . \mathrm{oa}=$ overlap area for central plate; $\csc =$ central sensory line; ioc.ot $=$ otic branch of infraorbital sensory line; ioc.pt $=$ postorbital branch of infraorbital sensory line; $\mathrm{lc}=$ main lateral line; $\mathrm{M}=$ marginal plate; $\mathrm{Nu}=$ nuchal plate orb = orbital opening; $\mathrm{P}=$ pineal plate; $\mathrm{PM}$ $=$ postmarginal plate $;$ pmc $=$ postmarginal sensory line; $\mathrm{PNu}=$ paranuchal plate; $\mathrm{PNu} . \mathrm{Oa}=$ overlap area for paranuchal plate; $\mathrm{PrO}=$ preorbital plate $; \mathrm{PtO}=$ postorbital plate $; \mathrm{R}=$ rostral plate; soc $=$ supraorbital sensory line.

\section{SYSTEMATIC PALAEONTOLOGY CLASS PLACODERMI M'Coy, 1848} ORDER ARTHRODIRA Woodward, 1891 Family Homostiidae Jaekel, 1903, emend.

Nomenclatural remark: The family name by Jaekel (1903) was Homosteidae. According to the International Code of Zoological Nomenclature (1999, Chapter 14, Article 63) the name-bearing type of a nominal familygroup taxon is a nominal genus called the "type-genus"; the family-group name is based upon that of the type genus. As the type genus is Homostius Asmuss, 1856, the family name should be Homostiidae, not Homosteidae as commonly used, e.g. by Denison, 1978. Still, some other authors have used the family name Homostiidae (White, 1978; Young, 2004). 


\section{Genus Tityosteus Gross, 1960}

Type species: Tityosteus rieversae Gross, 1960, emend.

Nomenclatural remark: The species name, T. rieversi, which is a male genitive, has to be emended, as it was Mrs $\mathrm{H}$. Rievers who gave the holotype to W. Gross for its description, and as the intention was to honor her, for which purpose the female genitive rieversae is appropriate.

Diagnosis (from Otto, 1992): A large arthrodire with the following combination of characters: T-shaped rostral plate. Preorbital plate wider than long and without preorbital process. Supraorbital sensory line runs along the whole length of preorbital plate. Anterolaterally placed orbital opening is situated at the lateral end of the suture of preorbital and postorbital plates and anteromesially of it. Anterior margin of central plate convex, its lateral margin straight; central plate shows no pit lines. Trunk shield with a median dorsal plate with approximately equal length and width (length/width $=0.9$ ); anterior dorsolateral plate with long condyle and small subglenoidal process; anterior lateral plate short and triangular. Ornament consists of sharp-topped tubercles with stellate bases.

Species content: Three taxa, all from the Emsian, Early Devonian: (1) the type species Tityosteus rieversae Gross, 1960, emend., locality Bundenbach, Rhineland, Germany, Hunsrück Schiefer; (2) Tityosteus orientalis Mark-Kurik, 1982, locality Perevozinskoe, South-Minusinsk Depression, southwestern East Siberia, Russia, Tashtyp Formation (Krasnov and Kurik, 1982); (3) Tityosteus cf. rieversae Gross, 1960, emend., locality Regajo-Parideras, Eastern Iberian Cordillera, southern Aragón, Spain, Mariposas Formation. Lehman (1976), on the basis of some poorly exposed remains, reported the occurrence of Tityosteus sp. from the Akka region, southern Morocco; after the complete preparation of the material, Lelièvre (1984) established that it belongs to a new Late Emsian homostiid, Antineosteus Lelièvre, 1984. It is noteworthy that the fish remains of the Hunsrück Schiefer, including those of $T$. rieversae, are from late within the Early Emsian, as is the Spanish $T$. cf. rieversae from the Mariposas Formation.

\section{Tityosteus cf. rieversae Gross, 1960, emend.} Fig. 1, 3A

Material: Only the right marginal plate from the head shield is known (Fig. 1). The specimen is deposited in the Museo Paleontológico de la Universidad Zaragoza, Spain, under the number MPZ 2003/825.

Description: The marginal plate (M) is a slender, almost flat plate from the lateral part of the skull roof (Fig. 2). The specimen described here is somewhat incomplete: the anterior and posterior ends and parts of margins, in particular that of the overlap area for the right central plate (C.oa), are broken. But

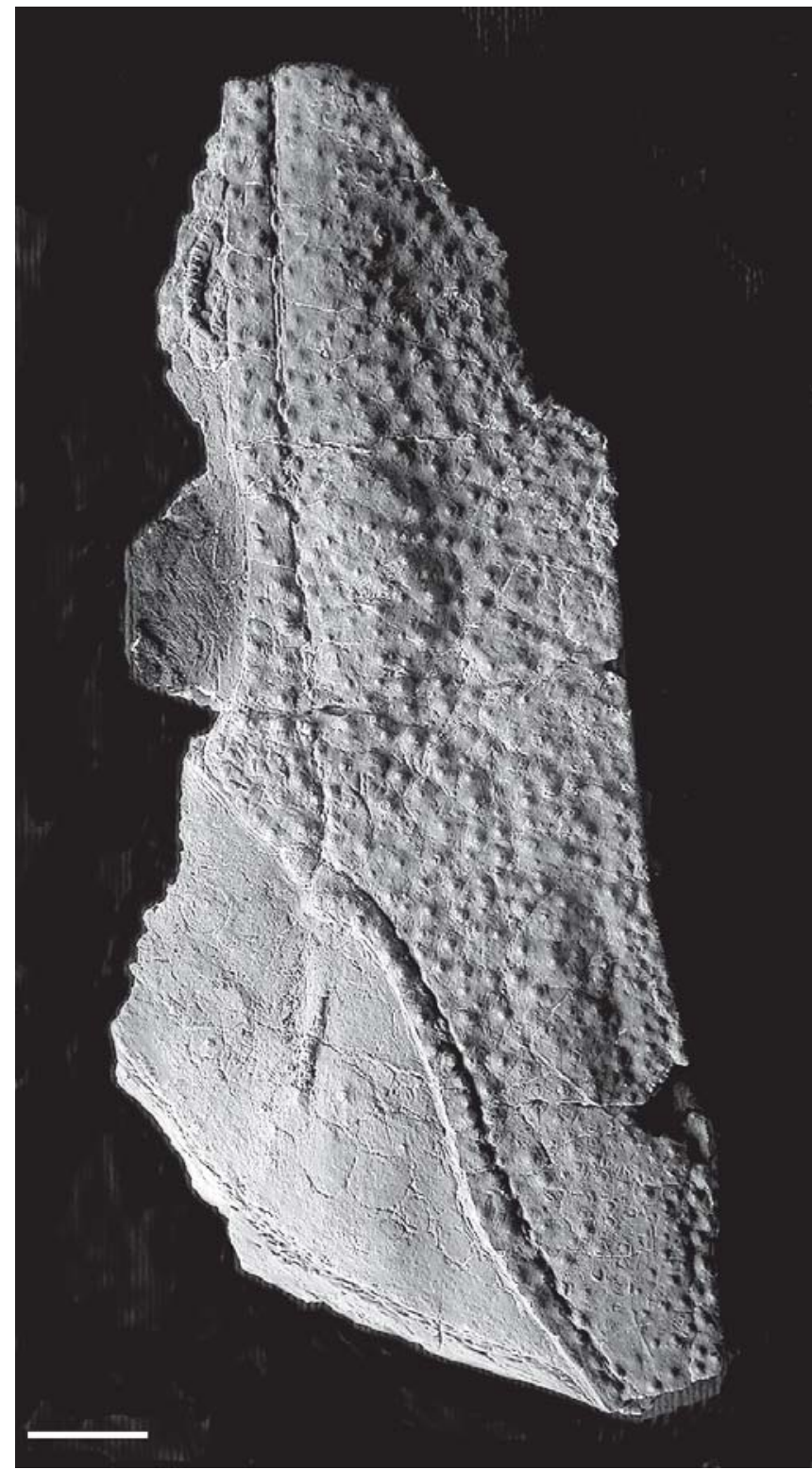

Figure 1. Tityosteus cf. rieversae Gross, 1960, emend. Right marginal plate, MPZ 2003/825. Scale bar is $1 \mathrm{~cm}$.

the general shape and overlap areas of the plate and the position of the sensory line grooves can be well traced and its configuration can be restored (Fig. 3A). The length of the fragmentary plate is $11.2 \mathrm{~cm}$ and its maximum width is $4.8 \mathrm{~cm}$. When restored, the length could be about $15 \mathrm{~cm}$. The plate is up to $3.5 \mathrm{~mm}$ thick. In T. rieversae the right marginal plate is $21 \mathrm{~cm}$ long and the left one $20.5 \mathrm{~cm}$ (Otto, 1992). The ornament of the plate consists of coarse tubercles, their density being about 4-7 per $\mathrm{cm}$. The ornamented surface of the marginal plate is much longer than wide; this shape is characteristic for the homostiids Tityosteus Gross, 1960, Antineosteus Lelièvre, 1984, Taemasosteus White, 1952, and Homostius Asmuss, 1856 (see Otto, 1992: fig. 7; Fig. 3 this paper). A very long and narrow marginal plate was described in a new Emsian representative of Homostiidae from Australia, Dhanguura johnstoni Young, 2004; this arthrodire has a narrow and long skull roof. The main 


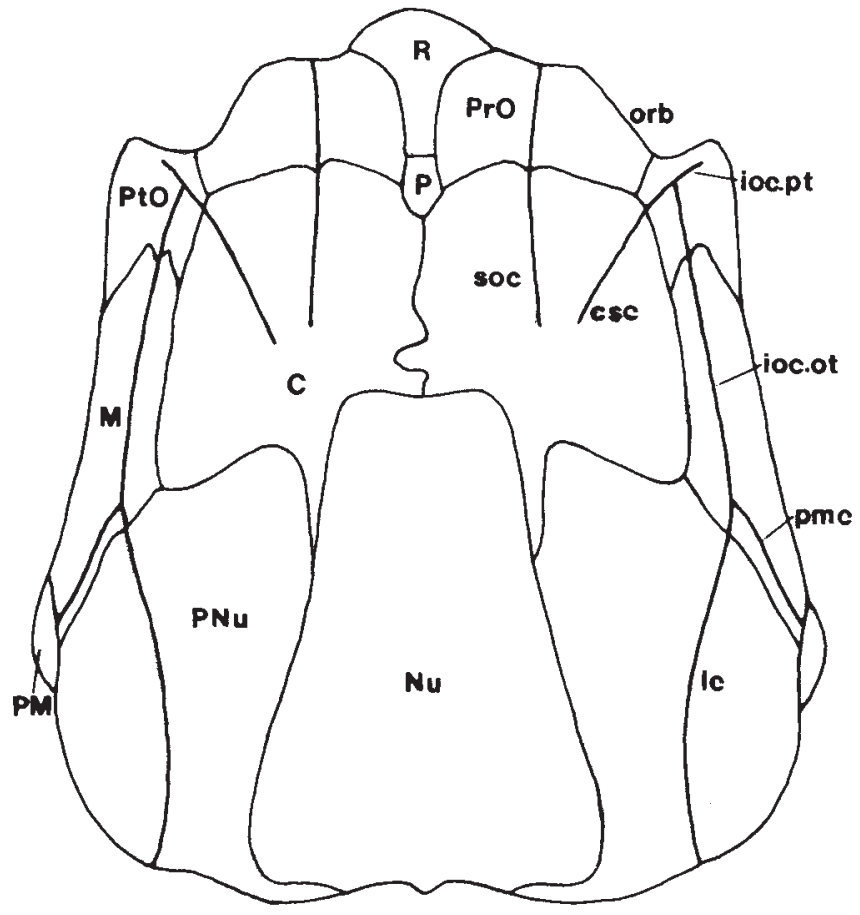

Figure 2. Tityosteus rieversae Gross, 1960, emend. Reconstruction of the skull roof, after Otto (1992: fig. 7e) (abbreviations in the figure are slightly modified). difference between the homostiid marginal plates lies in the position and length of the sensory line grooves. In the Early Devonian homostiids (Tityosteus, Antineosteus, Taemasosteus) the grooves of the infraorbital sensory line (ioc.ot) and the postmarginal sensory line $(\mathrm{pmc})$ run close to the sutures with the central $(\mathrm{C})$ and paranuchal $(\mathrm{PNu})$ plates and parallel to them (Fig. 3A-C). In the Middle Devonian Homostius the infraorbital sensory line (ioc.ot) runs along the midline of the ornamented surface or is situated slightly closer to the lateral margin of the plate (Fig. 3D). In Tityosteus the postmarginal sensory line (pmc) is longer than in Homostius, and it is the longest in Antineosteus.

The marginal plates of Tityosteus rieversae and Tityosteus cf. rieversae are fairly similar (Fig. 3B, 3A). In the latter the marginal plate and its overlap areas are somewhat wider and the posterior portion of the plate is longer. These differences may be due to intraspecific variability. The Spanish Tityosteus material is too limited to determine the species definitely. Judging by the marginal plate it is not excluded that we have in Aragón the same species as in the Rhineland, whereas in the Minusinsk Depression, Siberia, a different species (T. orientalis) occurs.

\section{Relationships}

Lelièvre (1988) discussed the relationships of Tityosteus, Antineosteus, Homostius, buchanosteids, and some other primitive brachythoracid arthrodires by means of a cladistic analysis. In a later classification of brachytho-
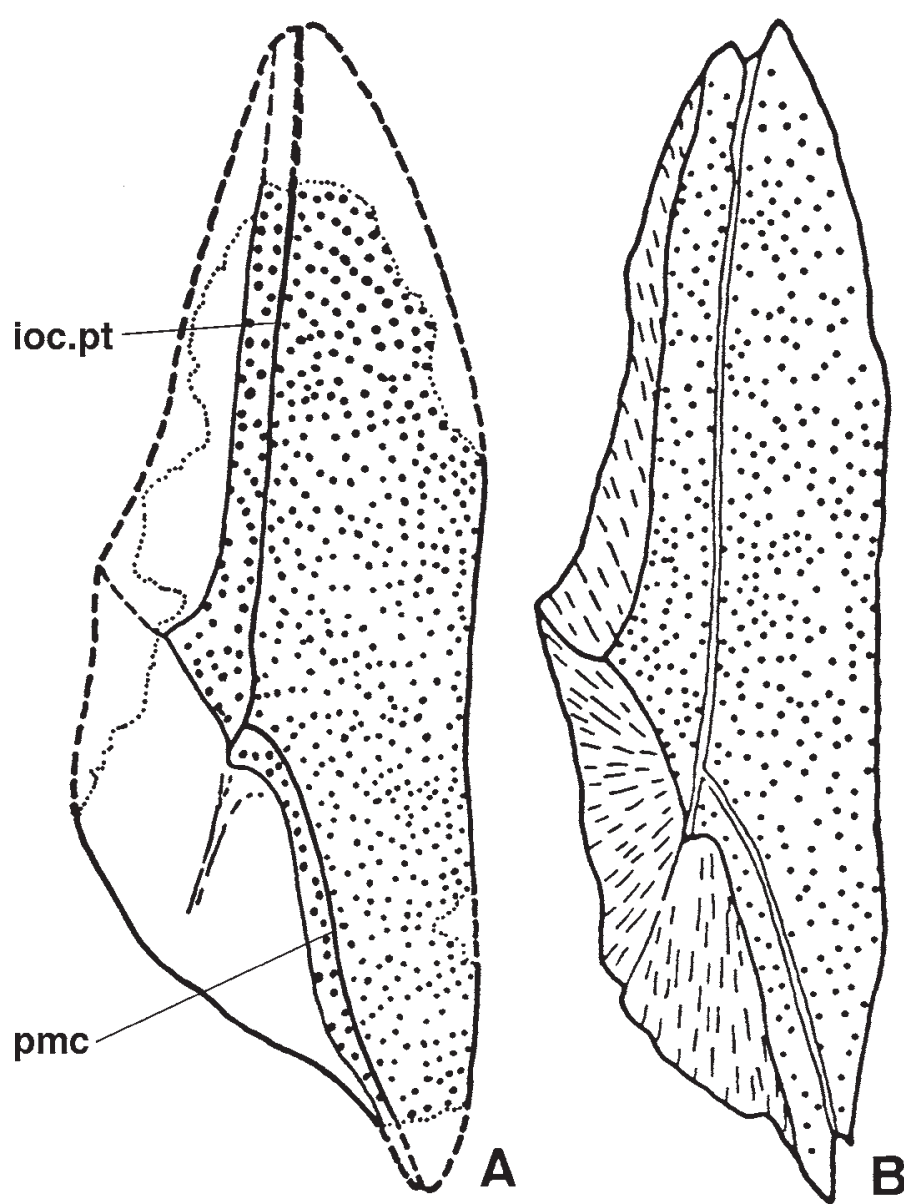
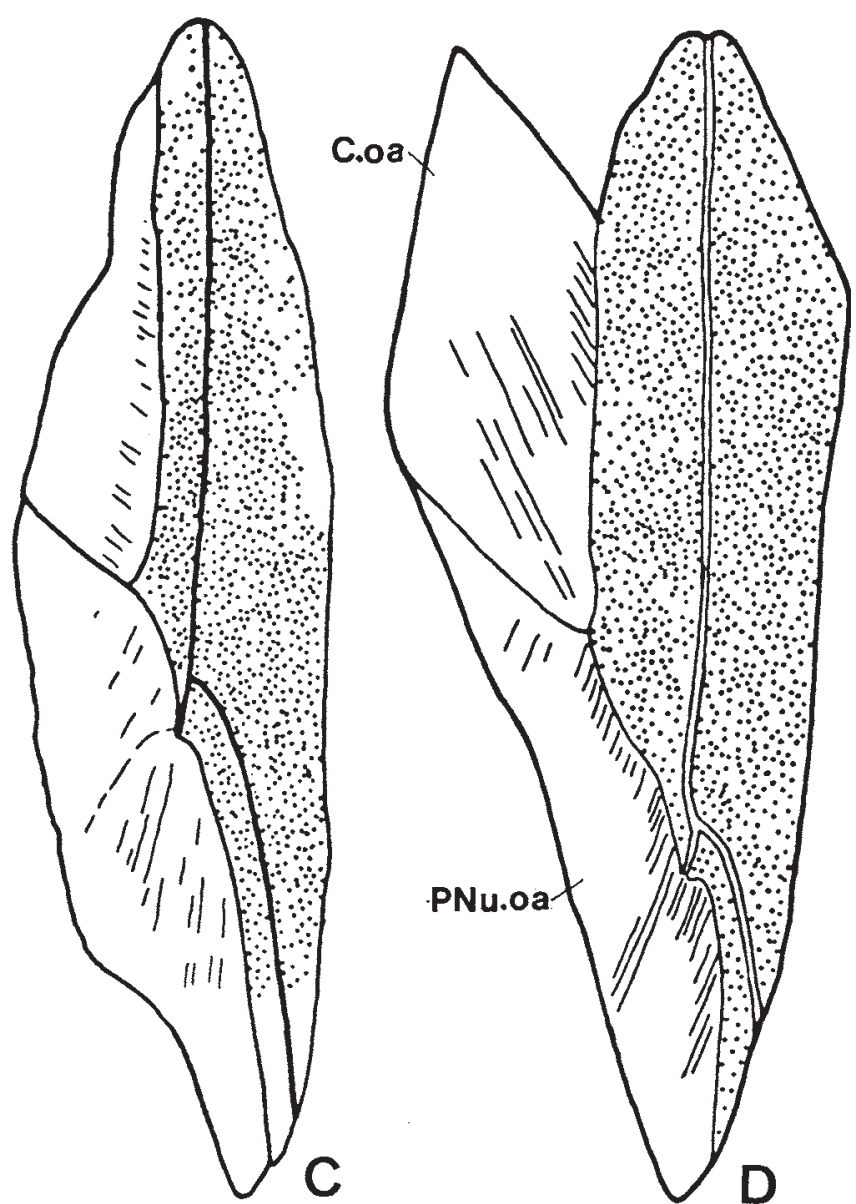


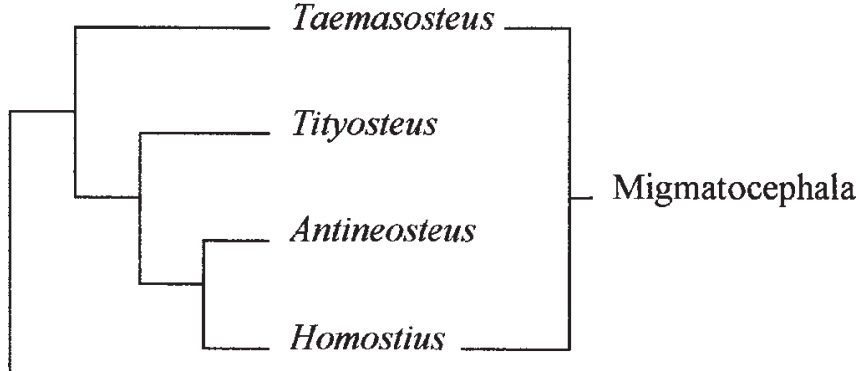

Eubrachythoraci

Figure 4. Relationships of the arthrodires of the clade (order) Migmatocephala (modified after Lelièvre, 1995: fig. 14).

racids presented by Lelièvre (1995; fig. 14) and figure 4, Tityosteus appeared as the sister taxon of the clade [Antineosteus + Homostius]. These genera belong to the order (clade) Migmatocephala erected by White (White and Toombs, 1972). Arthrodires of the clade Migmatocephala differ in a number of characters from the representatives of Eubrachythoraci, including Coccosteus, Holonema and several other forms (Lelièvre, 1995).

\section{Palaeoecological and palaeogeographical remarks}

Homostiids are large or very large arthrodires of late Early Devonian and Middle Devonian age. They were probably microphagous, because the more completely preserved forms have toothless or only finely denticulated lower jawbones (inferognathals). Toothless inferognathals are known in Homostius (Heintz, 1934; Mark-Kurik, 1992) and finely denticulated ones in Antineosteus (Lelièvre, 1984). The inferognathals of Tityosteus have not been found but could belong to either of these types. Denison (1978) suggested that Homostius fed on large quantities of plankton or small fry. According to MarkKurik (1992) this arthrodire might have resembled in its size and habitat the recent whale shark Rhinodon typicus. Another gigantic arthrodire with toothless inferognathals, Carolowilhelmina Mark-Kurik and Carls, 2002 in the Eifelian of Aragón, from similar facies as Tityosteus (Mark-Kurik and Carls, 2002), could have had the same kind of diet. In the paper mentioned, Carolowilhelmina was called a predator as a result of a minor error.

In Rhineland, Aragón, and Minusinsk Basin the representatives of the genus Tityosteus occur in predominantly Hercynic biofacies with good connections to open seas (in S and SE Europe, the Palaeotethys). Lelièvre (1984) dis-

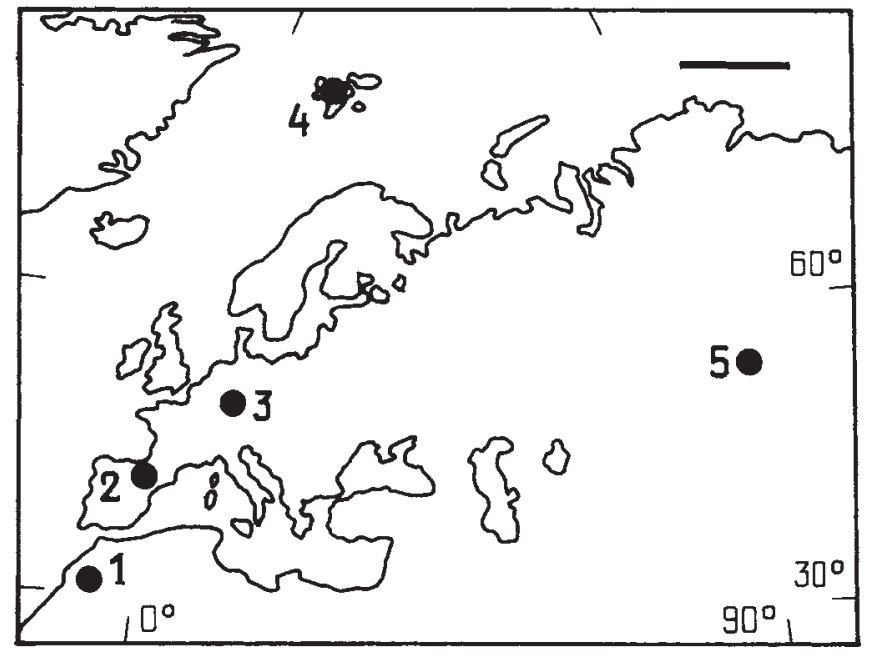

Figure 5. Distribution of the Early Devonian representatives of Migmatocephala shown on a map of present geography. 1, Antineosteus lehmani Lelièvre, 1984. 2, Tityosteus cf. rieversae Gross, 1960, emend. 3, Tityosteus rieversae Gross, 1960, emend. 4, Homostius arcticus Heintz, 1934. 5, Tityosteus orientalis MarkKurik, 1982. Scale bar is $1,000 \mathrm{~km}$.

cussed the distribution of the Early Devonian homostiids, including the Spitsbergen species of Homostius, H. cf. arcticus Heintz 1934 (see Ørvig, 1969: p. 283, fig. 4A). The latter appeared to be the only form coming from the Northern Hemisphere of the Devonian times (Lelièvre, 1984: fig. 21). Possible migration routes were indicated through Turkey, Iran, Afghanistan or through South America. According to the palaeogeographic reconstruction used by Lelièvre, three homostiids from the Devonian Southern Hemisphere (Tityosteus rieversae, Antineosteus, Taemasosteus) lived in areas fairly distant from each other but close to the palaeoequator. Young (1987: fig. 2) used a different palaeogeographical reconstruction. He showed Antineosteus and Taemasosteus in Gondwana, whereas Homostius and Tityosteus orientalis would live in Euramerica and Siberia, respectively. According to Young, most of the homostiid occurrences had a meridional arrangement and remained roughly between $35^{\circ}$ of northern and southern latitudes. In this reconstruction, only T. orientalis is more in the North, in the temperate zone. Thus, most of these big fishes appear as inhabitants of the tropical and / or subtropical zones.

The Early Emsian occurrences of Tityosteus in the Rhineland and in Aragón must have been closely con-

Figure 3. Reconstructions of the right marginal plates of: A, Tityosteus cf. rieversae Gross, 1960, emend. MPZ 2003/825. B, Tityosteus rieversae Gross 1960, emend. after Otto (1992: fig. 3e and fig. 8). C, Antineosteus lehmani Lelièvre, 1984 after Lelièvre (1984: figs.2, 3, 8 and pl. I). D, Homostius, reconstruction based on specimens of the right marginal plates 376-1, 3762 and the left central plate 376-3 in the collection of the Institute of Geology at the Tallinn University of Technology; Middle Devonian, Estonia, locality Karksi. Not to scale, all figures are drawn at uniform size. 
nected (Carls, 2003: figs. 2-3), because even turbidicolous brachiopod communities of shallow neritic environments that could not spread across wide oceans, had just migrated from Mauro-Ibero-Armorica (Ibarmaghia) into the Rhineland, as soon as the facies there ceased to be deltaic (Carls and Valenzuela-Ríos, 1998). In general, common shallow neritic (near shore) faunas make close palaeogeographic connections probable, whereas large fishes, like Tityosteus, that could cross open waters, may be indicative of palaeoclimatic similarities but not of palaeogeographic distances. As the plate kinematic models for the Devonian oceans are still uncertain and as the distribution of these homostiids does not contribute a closer hint to the palaeogeography, figure 5 is restricted to an image of their presently known occurrences.

\section{ACKNOWLEDGEMENTS}

The fossil described here has been recognized in the field by Dr. H. Mader as a placoderm remnant. Elga Mark-Kurik thanks the Estonian Science Foundation (Grant 5275) for its financial support. We kindly thank Dr. A. Blieck, Lille, for his critical and useful remarks on the manuscript.

\section{REFERENCES}

Asmuss, H. 1856. Das vollkommenste Hautskelett der bisher bekannten Tierreihe. Abhandlung zur Erlangung der Magisterwürde. Gedruckt bei Schünmanns Wittwe \& C. Mattiesen, Dorpat, 1-39.

Carls, P. 2003. Tornquist's Sea and the Rheic Ocean are illusive. Courier Forschungs-Institut Senckenberg, 242, 89-109.

Carls, P. and Valenzuela-Ríos, J.I. 1998. The ancestry of the Rhenish Middle Siegenian brachiopod fauna in the Iberian Chains and its palaeozoogeography (Early Devonian). Revista Española de Paleontología, $\mathrm{n}^{\circ}$ extr. Homenaje al Prof. Gonzalo Vidal, 123-142.

Denison, R.H. 1978. Handbook of Paleoichthyology. 2. Placodermi. Gustav Fischer Verlag, Stuttgart, 128 pp.

Gross, W. 1960. Tityosteus n.gen., ein Riesenarthrodire aus dem rheinischen Unterdevon. Paläontologische Zeitschrift, 34, 263-274.

Heintz, A. 1934. Revision of the Estonian Arthrodira. Part I. Family Homostiidae Jaekel. Archiv für die Naturkunde Estlands (I), 10, 180-290.

International Commission on Zoological Nomenclature. 1999. International Code of Zoological Nomenclature. 4th Edition, W.D.L. Ride, London, 306 pp.

Jaekel, O. 1903. Über die Organisation und systematische Stellung der Asterolepiden. Zeitschrift der deutschen geologischen Gesellschaft, 55, 41-60.
Krasnov, V.N. and Kurik, E. 1982. [First find of fossil fish in limestones of the Tashtyp Formation of the SouthMinusinsk Depression.] In: Stratigraphy and Palaeontology of the Devonian and Carboniferous (Ed. O.V. Yuferev). Transactions of the Institute of Geology and Geophysics, Academy of Sciences of the USSR, Siberian Branch, 483, 47-52 [in Russian].

Lehman, J.P. 1976. Nouveaux Poissons fossiles du Dévonien du Maroc. Annales de Paléontologie (Vertébrés), 62 1-34.

Lelièvre, H. 1984. Antineosteus lehmani n.g., n.sp., nouveau Brachythoraci du Dévonien inférieur du Maroc présaharien. Annales de Paléontologie, 70, 115-158.

Lelièvre, H. 1988. Nouveau matériel d'Antineosteus lehmani Lelièvre, 1984 (Placoderme, Brachythoraci ) et d'Acanthodiens du Dévonien inférieur (Emsien) d'Algérie. Bulletin du Muséum national d'Histoire naturelle, $4^{\mathrm{e}}$ série, section C, 10, 287-302.

Lelièvre, H. 1995. Description of Maideria falipoui n.g. n.sp., a long snouted brachythoracid (Vertebrata, Placodermi, Arthrodira) from the Givetian of Maider (South Morocco), with a phylogenetic analysis of primitive brachythoracids. Bulletin du Muséum national d'Histoire naturelle, $4^{\mathrm{e}}$ série, section C, 17, 163-207.

Mark-Kurik, E. 1992. The inferognathal in the Middle Devonian arthrodire Homostius. Lethaia, 25, 173-178.

Mark-Kurik, E. and Carls, P. 2002. A long-snouted late Eifelian arthrodire from Aragón, Spain. Revista Española de Paleontología, 17, 117-135.

Ørvig, T. 1969. Vertebrates from the Wood Bay Group and the position of the Emsian-Eifelian boundary in the Devonian of Vestspitsbergen. Lethaia, 2, 273-328.

Otto, M. 1992. Ein Neufund des brachythoracen Arthrodiren Tityosteus rieversi aus dem unterdevonischen Hunsrückschiefer des rheinischen Schiefergebirges. Neues Jahrbuch für Geologie und Paläontologie, Abhandlungen, 187, 53-82.

White, E.I. 1952. Australian arthrodires. Bulletin of British Museum (Natural History), Geology, 1, 249-304.

White, E.I. 1978. The larger arthrodiran fishes from the area of the Burrinjuck Dam, N.S.W. Transactions of the Zoological Society of London, 34, 149-262.

White, E.I. and Toombs, H.A. 1972. The buchanosteid arthrodires of Australia. Bulletin of the British Museum (Natural History) Geology, 22, 379-419.

Young, G.C. 1987. Devonian palaeontological data and the Armorica problem. Palaeogeography, Palaeoclimatology, Palaeoecology, 60, 283-304.

Young, G.C. 2004. Large brachythoracid arthrodires (placoderm fishes) from the Early Devonian of Wee Jasper, New South Wales, Australia, with a discussion of basal brachythoracid characters. Journal of Vertebrate Paleontology, 24, 1-17.

Manuscrito recibido: 10 de noviembre, 2003 Manuscrito aceptado: 1 de septiembre, 2004 